\title{
Revitalisasi peran perguruan tinggi dalam menangani gerak radikalisme dan fenomena melemahnya bela negara di kalangan mahasiswa
}

\author{
Leni Anggraeni ${ }^{a, 1^{*}}$, Cecep Darmawan ${ }^{\text {b,2 }}$, Sri Wahyuni Tanshzil ${ }^{c, 3}$ \\ a, b, c Departemen Pendidikan Kewarganegaraan, Universitas Pendidikan Indonesia, Bandung \\ ${ }^{1}$ anggraeni@upi.edu ; ${ }^{2}$ cecepdarmawan@upi.edu; ${ }^{3}$ sriwahyunistanshzil@upi.edu \\ ${ }^{*}$ korespondensi penulis
}

\begin{abstract}
ABSTRAK
Paham radikal semakin merisaukan karena berkembang pada kelompok strategis yaitu pemuda. Penyebaran melalui media sosial dengan kemunculan hoax serta beberapa situs web radikal menjadi tren baru serta andalan kaum teroris dalam menyebarkan pahamnya. Gerakan radikalisme sangat masif, terorganisir dan berbahaya. Hal ini diperparah dengan lemahnya semangat bela negara dikalangan mahasiswa. Oleh karenanya penanganannya pun harus dilaksanakan secara komprehensif yang salah satunya melalui revitalisasi peran perguruan tinggi di Jawa Barat. Pendekatan yang digunakan dalam penelitian ini adalah kualitatif dengan metode deskriptif. Responden dalam penelitian adalah dosen, pimpinan bidang kemahasiswaan dan mahasiswa pada beberapa Universitas di Jawa Barat (UPI, Unpad, UIN Bandung, ITB, dan IPB). Tujuan penelitian adalah mengetahui peran Perguruan Tinggi di Jawa Barat dalam menangani gerak radikalisme dan fenomena melemahnya bela negara dikalangan mahasiswa. Berdasarkan hasil penelitian, dapat diketahui bahwa peran perguruan tinggi dalam menangani gerak radikalisme dan fenomena melemahnya bela negara dapat dilaksanakan melalui tiga jalur utama, yaitu melalui pembelajaran Mata Kuliah Umum (MKU), lembaga kemahasiswaan, dan organisasi kemahasiswaan. Kata kunci: perguruan tinggi, penanganan gerak radikalisme, mahasiswa
\end{abstract}

\begin{abstract}
Radicalism is increasingly troubling because it develops in strategic groups, namely youth. Spreading through social media with the emergence of hoaxes and several radical websites has become a new trend and a mainstay of terrorists in spreading their understanding. The radicalism movement is very massive, organized, and dangerous. It compounded by the weak spirit of defending the country among students. Therefore, the handling must carried out comprehensively, one of which is through revitalizing the role of universities in West Java. The approach used in this research is qualitative with descriptive methods. Respondents in the study were lecturers, student leaders, and students at several universities in West Java (UPI, Unpad, UIN Bandung, ITB, and IPB). The purpose of the study to determine role of universities in West Java in dealing with the movement of radicalism and the phenomenon of weakening the national defense among students. Based on the results of the study, it can seen that the role of Higher Education in dealing with the movement of radicalism and the phenomenon of weakening state defense can carried out through three main channels, namely through General Courses (MKU), Student Institutions, and Student Organizations.
\end{abstract}

Keywords: higher education, the encounter of radicalism, student,

Copyright (C2019 Universitas Ahmad Dahlan, All Right Reserved

\section{PENDAHULUAN}

Hasil Penelitian Lembaga Ilmu Pengetahuan Sosial (LIPI) tahun 2016 mengungkapkan bahwa pengaruh paham radikal semakin merisaukan karena berkembang pada kelompok strategis yaitu mahasiswa. Berbagai fenomena bom bunuh diri, terbongkarnya jaringan NII (Negara Islam Indonesia) beberapa waktu lalu mengingatkan bahwa gerakan radikalisme telah memperluas jaringanya melalui kampus dan sekolah, posisinya yang strategis karena memiliki jangkauan pergaulan yang luas serta otonom menjadi sarana yang paling pas untuk memproliferasi paham radikal yang diperjuangkan oleh suatu kelompok tertentu (Hanani, 2013). Selain itu, Lembaga
Kajian Islam dan Perdamaian (BBC, 2011) menemukan bahwa dikalangan 1000 responden pelajar di 100 SMP dan SMA Swasta dan Negeri di Jakarta, Bogor, Depok dan Tangerang, 48,9\% siswa mengatakan mereka mendukung aksi kekerasan atas nama agama. Hal tersebut merupakan beberapa bukti yang mengindikasikan bahwa permasalahan terkait isu radikalisme menjadi isu yang strategis dan penting untuk diteliti sebagai kajian akademis.

Pada dasarnya, terdapat tiga alasan bahaya gerakan radikalisme dan terorisme bagi Indonesia yaitu: 1) merupakan kejahatan terorganisir, karena adanya jaringan gerakan radikalisme dan terorisme yang terdiri dari: penyandang dana, korlap, 
operator lapangan, mobilitas tinggi serta tertutup; 2) bersifat kejahatan lintas negara, karena gerakan radikalisme ini merupakan kelompok yang berasal dari dalam dan luar negeri; 3) akibat yang ditimbulkan dari kejahatan tersebut bersifat luar biasa (extraordinary crime), karena gerakan ini menciptakan bahaya besar, indiscrimination orangorang yang tidak bersalah, menggunakan senjata massal, level teroris bersifat nasional dan international serta membahayakan perdamaian nasional dan internasional (Apriliana, Raharjanti, Sulastri, Noviana, \& Nur, 2017; Badan Nasional Penanggulangan Terorisme, 2016; Capalbo, 2011; Takwin, Mudzakkir, Salim, Ahnaf, \& Hamdi, 2016). Fakta tersebut cukup menjadi sebab bahwa kajian terkait upaya deradikalisasi penting untuk dilaksanakan. Disamping sebagai upaya penguatan nilai-nilai idiil Pancasila, upaya deradikalisasi pun memiliki fungsi sebagai ketahanan dan bela Negara yang merupakan tugas seluruh elemen warga Negara, tidak terkecuali para akademisi.

Penelitian ini merupakan bentuk varian grand strategy dalam upaya deradikalisasi serta bela negara sebagaimana yang diamanatkan oleh Pancasila dan Pembukaan UUD 1945 yang dilatarbelakangi oleh realita permasalahan kebangsaan yang berkembang saat ini, seperti: munculnya aliran/golongan radikal, disorientasi dan belum melembaganya bela negara; keterbatasan perangkat kebijakan terpadu dalam mewujudkan nilai-nilai kecintaan terhadap tanah air; bergesernya nilai etika dalam kehidupan berbangsa dan bernegara; memudarnya kesadaran terhadap nilai-nilai budaya bangsa; ancaman disintegrasi bangsa; dan melemahnya kemandirian (Pemerintah Republik Indonesia, 2010). Oleh karena itu diperlukan pendekatan yang bersifat soft approach (deradikalisasi) dengan cara counter radical ideology melalui penguatan pendidikan bela negara yang diintegrasikan dalam berbagai kondisi pada lingkungan kampus. Pada Mata Kuliah Umum Pendidikan Kewarganegaraan, rangkaian program pada lembaga kemahasiswaan serta organisasi kemahasiswaan.

\section{METODE}

Metode yang digunakan dalam penelitian ini adalah metode Research and Development (R\&D). Pemilihan metode tersebut didasarkan pada tujuan yang hendak dicapai peneliti, yakni melahirkan suatu produk berupa media CICOMDI (Civic Comic Digital) sebagai upaya Deradikalisasi dan Penguatan Bela Negara bagi Pemuda umumnya dan mahasiswa pada khususnya.

Hasil penelitian pengembangan tidak hanya pengembangan sebuah produk yang sudah ada, melainkan juga untuk menemukan pengetahuan atau jawaban atas permasalahan praktis. Subjek dalam penelitian ini tersebar di lima Perguruan Tinggi Jawa Barat, yaitu UPI, ITB, UNPAD, IPB dan UIN Sunan Gunung Djati. Dengan jumlah 502 orang mahasiswa. Teknik pengumpulan data meliputi: wawancara mendalam (indepth interview); studi literatur; observasi partisipatif.

\section{HASIL DAN PEMBAHASAN}

\section{A. Memahami Radikalisme di Kampus}

Kata "radikal" berasal dari kata radix yang berarti akar. Maksudnya, radikal dapat bermakna kritis atau berpikir secara komprehensif. Walaupun demikian, ada perbedaan konsep tentang makna radikal dan radikalisme. Dalam pandangan Simon Tormy (Azca, 2013, hal. 25), radikalisme merupakan sebuah konsep yang meletakan posisi sebagai antitesis dari arus utama (mainstream). Dalam pandangannya radikalisme tidak memberi makna gagasan atau argumentasi, tetapi lebih pada arah sebuah ideologi atau posisi yang menggugat sesuatu yang telah dianggap mapan, diterima secara umum. Sehingga dalam pandangannya bisa saja menjadi "radikal" pada satu periode menjadi bersalin pada posisi "mainstream" di era berikutnya atau era lain.

Banyak pakar yang mengemukakan pandangannya tentang akar kemunculan radikalisme, salah satu diantaranya ialah pendapat dari Ummah (2012, hal. 115) yang menyatakan tentang faktor utama yang menjadi sebab kemunculan radikalisme adalah: pertama, adanya tekanan politik penguasa terhadap keberadaannya. Munculnya radikalisme di Indonesia disebabkan oleh adanya otoritarianisme (Azra, 1996, hal. 18); kedua, adanya emosi keagamaan atau biasa kita kenal dengan sentimen keagamaan. Hal ini muncul sebagai sebuah solidaritas atas kekerasan atau ketidakadilan terhadap saudara oleh kekuatan tertentu, dengan dalih membela agama, jihad dan mati syahid; ketiga, faktor kultural; keempat, faktor ideologis antiwesternisme. Dalam hal ini simbolsimbol asing harus dihancurkan demi menegakan syariat Islam; kelima, faktor kebijakan pemerintah. Ketidakmampuan pemerintah dalam menjaga kestabilan ekonomi dan memberikan kesejahteraan terhadap rakyatnya yang ditopang oleh beberapa faktor baik, faktor ekonomi, politik, budaya, serta penegakan hukum menjadi pemicu adanya gerakan - gerakan radikalisme; keenam, media masa. lontaran yang kurang baik dari media masa barat terhadap Islam, menjadi salah satu alasan munculnya gerakan radikalisme di Indonesia.

Namun pertanyaan berikutnya adalah apa alasan kemunculan gerakan radikalisme di kampus? Apa yang menjadi latarbelakang kemunculannya? Gerakan radikalisme di lingkungan kampus ini diawali dengan pemahaman agama yang kurang mendalam dari kalangan 
mahasiswa, serta adanya fasilitas dukungan dari kondisi biologis mahasiswa yang belum matang (Arifuddin, 2016, hal. 453). Mudahnya mahasiswa mengalami fase krisis identitas menjadi salah satu faktor penentu kecenderungan untuk bergabung dengan kelompok radikal. Menurut Wiktorowicz (2004, hal. 85), dalam situasi 'krisis identitas' seseorang biasanya cenderung lebih mudah mengalami apa yang disebutnya sebagai 'pembukaan kognitif' (cognitive opening): sebuah fase penting yang dialami oleh seorang aktivis untuk bergabung dengan gerakan radikal, yang lazim diawali dengan sebuah krisis di mana mereka mengalami ketidakpastian, termasuk menyangkut identitas diri, sehingga mereka menjadi mudah menerima kemungkinan ide-ide dan pandanganpandangan hidup baru. Proses 'pembukaan kognitif' misalnya terjadi sebagai buah dari persinggungan dan pergaulan dengan ajaran-ajaran kelompok Islam radikal, baik yang bercorak politik, salafi maupun jihadi (Azca, 2013, hal. 40).

\section{B. Peran Strategis Perguruan Tinggi dalam Menangani Gerak Radikalisme Mahasiswa}

Berdasarkan hasil penelitian di lapangan melalui wawancara, studi dokumentasi serta literasi, dapat diketahui bahwa kekuatan perguruan tinggi di Jawa Barat dalam mengurangi kegiatan radikalisasi yang berada di dunia kampus, dilaksanakan melalui tiga lembaga strategis, yaitu Departemen MKU, lembaga kemahasiswaan dan organisasi kemahasiswaan. Ketiga lembaga di perguruan tinggi ini memiliki tugas dan fungsi yang berbeda, baik dari segi kelembagaan maupun secara substansial. Dari unsur kelembagaan kampus, peran Lembaga Kemahasiswaan memiliki pengaruh yang sangat strategis untuk memberikan pengetahuan mengenai kenegaraan kepada mahasiswa.

Bentuk kegiatan yang dilakukan oleh Lembaga Kemahasiswaan dilakukan melalui tiga pendekatan yaitu pendekatan keilmuan, kesejahteraan dan keprofesian. Hal ini dipandang sebagai cara yang efektif untuk mencegah paham radikalisme masuk pada dunia kampus karena jika menggunakan pendekatan yang bersifat hukum, hal tersebut dirasa kurang manusiawi dan cenderung bersifat indoktrinasi, maka perlu melakukan pendekatan lain, seperti pendekatan kesejahteraan agar mahasiswa bisa lebih fokus untuk memahami kenegaraan dengan baik. Sehingga dapat disimpulkan bahwa pendekatan yang dilakukan oleh perguruan tinggi sebagai upaya deradikalisasi pada mahasiswa, tidak hanya dilakukan melalui cara-cara keilmuan dari segi keagamaan atau kenegaraan, akan tetapi menyentuh pada ranah kesejahteraan mahasiswa dan pengembangan profesi mahasiswa. Pendekatan kesejahteraan dalam proses deradikalisasi yang dilakukan oleh Lembaga Kemahasiswaan menjadi sangat strategis, karena dengan sendirinya mahasiswa tidak akan memikirkan paham-paham radikalisme dan fokus pada pengembangan kemampuannya. Selain pada pendekatan kesejahteraan, Lembaga Kemahasiswaan dan umumnya Institut Teknologi Bandung harus dapat melakukan deteksi secara dini (early warning) terhadap pergerakan paham radikal baik yang melalui proses dari atas ke bawah (topdown process) yang dilakukan oleh pihak luar, maupun yang dilakukan dari bawah ke atas (bottomup process) yakni individu sendiri mengeksplorasi paham radikal melalui berbagai sumber sehingga dirinya terinfiltrasi (Ramadhan, 2016).

Pada aspek pembelajaran departemen MKU memegang peran penting dalam proses deradikalisasi atau boleh dikatakan menjadi ujung tombak kegiatan deradikalisasi, karena pembelajarannya menyeluruh kepada semua mahasiswa, pembelajaran departemen MKU memiliki banyak aspek seperti aspek keagamaan, kenegaraan, politik maupun hukum yang bertujuan untuk membentuk mahasiswa yang mempunyai kesadaran akan hidup berbangsa dan bernegara. Kegiatan pembelajaran ini menjadi sangat penting karena dalam proses pembelajaran akan mengubah mahasiswa dari segi kognitif, afektif dan psikomotor. Sehingga akan terjadi perubahan tingkah laku mahasiswa sesuai dengan yang tercantum dalam Pancasila dan Undang-Undang Dasar 1945. Selain itu, departemen MKU juga mengadakan suatu kegiatan diluar jam pelajaran, seperti ada simposium kebangsaan dengan menghadirkan pemateri yang ahli dalam bidang kenegaraan. Hal ini tentu akan menambah fungsi dari Departemen MKU menjadi sangat penting dalam melakukan bela negara bagi mahasiswa, karena dilihat dari sumber pembelajaran tidak hanya dari buku, akan tetapi langsung dari tokoh yang memegang peran penting dalam kehidupan berbangsa dan bernegara.

Dalam pelaksanaan kegiatan deradikalisasi yang dilakukan departemen MKU supaya lebih optimal harus adanya sinergitas antara setiap mata kuliah yang ada di departemen MKU, karena persoalan bela negara menyangkut banyak unsur baik kenegaraan, sosial, agama, hukum maupun politik. Sehingga jika terjadi perbedaan pandangan dalam pelajaran, akan mengakibatkan kontradiksi dalam pembelajaran yang mengakibatkan mahasiswa kebingungan mencari sumber yang tepat.

Departemen MKU dalam optimalisasi kegiatan bela negara perlu mengembangkan suatu model pendidikan yang dapat mencegah pada suatu desain utuh yang memuat kerangka pandang yang mendasar (philosophical foundation) terhadap Islam, materi, model pembelajaran, serta lingkungan yang 
dapat menumbuhkan pengetahuan dan sikap pengakuan, toleran dan kooperatif terhadap pihak yang berbeda baik karena alasan agama, paham keagamaan, budaya dan lain sebagainya (Ramadhan, 2016).

Dari unsur mahasiswa tentu peran yang sangat strategis dipegang oleh ormawa, karena secara ruang lingkup bukan hanya pada ranah departemen atau fakultas, akan tetapi pada seluruh ranah kampus. Kegiatan yang dilakukan oleh ormawa menurut pandangan Tim Peneliti lebih fokus pada ranah praktik dari pada ranah konsep dan teori, terutama yang dilakukan oleh kementerian Sosial Politik yang memiliki program kerja yang khas dengan penyampaian aspirasi mahasiswa yaitu melalui aksi demonstrasi. Kegiatan ini tidak bisa dianggap sebagai kegiatan yang bersifat radikal, karena demonstrasi merupakan bagian dari hak menyatakan pendapat dan hal itu tercantum dalam Undang-Undang Dasar 1945. Hal ini menandakan bahwa kegiatankegiatan yang dilakukan oleh ormawa merupakan kegiatan yang positif selama dijalankan sesuai dengan peraturan yang berlaku, justru hal ini sangat baik sebagai kontrol terhadap negara dalam menerapkan setiap kebijakannya.

\section{Upaya yang Dilakukan oleh Perguruan Tinggi Negeri di Jawa Barat dalam Memberikan Penguatan Bela Negara bagi Mahasiswa}

Memberikan penguatan bela negara bagi kalangan pemuda yang dilakukan oleh perguruan tinggi, dilakukan oleh tiga komponen yakni lembaga kemahasiswaan, departemen mata kuliah umum dan organisasi kemahasiswaan. Dalam proses penguatan terhadap bela negara, maka penting untuk membuat perencanaan yang baik sebagai upaya memberikan penguatan bela negara dikalangan pemuda. Suatu kegiatan bela negara yang baik perlu dilakukan dengan perencanaan yang matang, agar dalam pelaksanaannya dapat diukur tingkat keberhasilannya, serta setiap tindakan yang terjadi dalam pelaksanaan dapat terkontrol dengan baik, sehingga kegiatan bela negara dapat berjalan dengan efektif dan efisien.

Perencanaan memegang peranan penting dalam berbagai kegiatan yang dilakukan, termasuk kegiatan bela negara, karena dengan adanya perencanaan kegiatan, jika dalam pelaksanaannya berbeda maka dapat diminimalisir potensi kegagalannya. Perguruan tinggi di Jawa Barat memiliki tiga lembaga yang berkaitan dengan proses perencanaan kegiatan bela negara, yaitu Lembaga Kemahasiswaan, Departemen Mata Kuliah Umum dan Organisasi Kemahasiswaan. Ketiga lembaga ini mempunyai tugas dan fungsi yang berbeda dalam menjalankan kegiatan bela negara bagi mahasiswa. Dikaitkan dengan kewajiban perguruan tinggi sebagaimana yang tercantum dalam Pasal 20 ayat (2) Undang-Undang Republik Indonesia Nomor 20 Tahun 2003 tentang Sistem Pendidikan Nasional bahwa "perguruan tinggi berkewajiban menyelenggarakan pendidikan, penelitian, dan pengabdian kepada masyarakat". Maka seyogiannya perencanaan yang dilakukan oleh perguruan tinggi harus berorientasi pada tridharma perguruan tinggi atau dapat diartikan bahwa perencanaan kegiatan deradikalisasi mahasiswa harus menyangkut pada aspek pendidikan, penelitian dan pengabdian pada masyarakat. Perencanaan deradikalisasi yang menyangkut kedalam pendidikan, penelitian dan pengabdian akan berdampak baik, bukan hanya pada terciptanya budaya damai di lingkungan perguruan tinggi, akan tetapi terciptanya budaya damai di lingkungan masyarakat karena dampak dari penelitian dan pengabdian mahasiswa dirasakan secara langsung oleh masyarakat.

Upaya penguatan kegiatan bela negara yang dilakukan oleh Lembaga Kemahasiswaan dilakukan melalui: 1) melalui evaluasi program tahun lalu, 2) berorientasi pada kebutuhan mahasiswa, 3) akses kejuaraan bagi mahasiswa, 4) koordinasi dengan para wakil dekan bidang akademik, dan 5) koordinasi dengan wakil rektor bidang akademik. Kegiatan perencanan ini dapat dilihat dalam dua aspek, yaitu secara kelembagaan maupun secara substansi. Secara kelembagaan tentu ini sangat baik, karena faktor sistem lembaga akan menentukan keberhasilan dalam perencanaan kegiatan, maupun pada saat pelaksanaan. Selain itu, pada aspek substansial dengan melihat kebutuhan mahasiswa, ini merupakan cara yang baik agar kegiatan yang dilakukan dapat diterapkan secara efektif dan efisien. Secara teknis perencanaan kegiatan bela negara lembaga kemahasiswaan tidak ada yang berbeda dengan perencanaan umum dalam setiap kegiatan yang dilakukan oleh lembaga-lembaga di perguruan tinggi. Akan tetapi, yang harus menjadi perhatian khusus dari lembaga kemahasiswaan dan perguruan tinggi secara umumnya yaitu harus adanya kegiatan yang bertujuan untuk mengkritisi karya-karya yang dihasilkan dalam konteks kenegaraan seperti peraturan dan kebijakan pemerintah, saat ini perguruan tinggi belum berani membuat kegiatan yang bertujuan untuk mengkritisi peraturan dan kebijakan pemerintah, padahal hal tersebut merupakan kegiatan yang harus dilakukan oleh perguruan tinggi (Susanti, 2013).

Dampak dari perencanaan kegiatan yang tidak berorientasi pada mendekatkan kehidupan mahasiswa dengan kebijakan-kebijakan pemerintah, membuat mahasiswa secara insiatif 
membuat kegiatan pengkajian terhadap peraturan dan kebijakan atas dasar yang kurang ilmiah. Sehingga muncul gerakan-gerakan mahasiswa yang ingin menentang peraturan dan kebijakan tanpa dasar yang ilmiah, sehingga hanya didasarkan pada cara berpikir radikal yang ingin mengubah tataran kenegaraan secara cepat.

Kegiatan deradikalisasi yang dilakukan oleh perguruan tinggi khususnya yang dilakukan oleh Lembaga Kemahasiswaan sangat baik, melakukan kegiatan deradikalisasi dengan pendekatan keprofesian dan hasil yang didapat memang sangat baik. Akan tetapi dalam membangun negara tentu lepas dari unsur pemahaman mahasiswa mengenai kenegaraan, maka Lembaga Kemahasiswaan selain untuk melakukan kegiatan yang bersifat keprofesian harus juga menguat pelatihan-pelatihan terhadap mahasiswa yang berorientasi pada pengembangan pengetahuan mahasiswa mengenai kenegaraan, karena perguruan tinggi menjadi wahana yang strategis untuk melakukan pelatihanyaitu sebagai pusat pelatihan manusia (Susanti, 2013).

Pada tataran pembelajaran yang dilakukan oleh departemen mata kuliah umum (MKU) sama dengan perencanaan yang dilakukan pada mata kuliah lainnya, akan tetapi yang menjadi fokus dari perencanaan pembelajarannya yaitu melihat karakteristik mahasiswa yang berbeda dengan mahasiswa sosial. Pentingnya melihat karakteristik mahasiswa, karena pembelajaran yang baik harus dapat disesuaikan dengan karakteristik mahasiswa, karena hal ini akan mengakibatkan cara pemilihan model pembelajaran dan strategi mengajar. Ini menandakan bahwa perencanaan yang dilakukan oleh Departemen MKU sangat penting dalam proses pembelajaran yang akan dilakukan, mengingat materi

Pembelajaran harus disesuaikan dengan konteks keagamaan dan kenegaraan. Dalam perencanaan kegiatan deradikalisasi yang dilakukan oleh Departemen MKU menjadi unsur yang sangat penting terutama di perguruan tinggi, karena pada mata pelajaran MKU terdapat pelajaran humaniora. Sebagaimana Point c Pasal 4 Undang-Undang Republik Indonesia Nomor 12 Tahun 2012 tentang Pendidikan Tinggi menyatakan bahwa fungsi perguruan tinggi yaitu mengembangkan ilmu pengetahuan dan teknologi dengan memperhatikan dan menerapkan nilai humariona. Secara hukum positif yang ada di Indonesia peran dari Departemen MKU sangat sentral dalam menerapkan nilai-nilai kemanusiaan, maka setiap perencanaan yang dilakukan oleh Departemen MKU perlu menguatkan unsur kemanusiaan dalam setiap pelajarannya. Kegiatan deradikalisasi yang dilakukan oleh Departemen MKU, dimulai dengan perencanaan kegiatan, berupa perencanaan pembelajaran. Perencanaan pembelajaran sangat penting karena seorang pendidik sejenius apapun punya keterbatasan. Keterbatasan tersebut harus disadari sepenuhnya untuk diantisipasi agar ketika di tengah peserta didiknya mampu menjadi motivator dalam proses pembelajaran yang mencerdaskan (Sholeh, 2007). Dalam mencegah kegiatan pemikiran radikalisme peran dari Departemen MKU sangat strategis, karena dilakukan secara berkelanjutan dalam satu semester dan dengan pertemuan yang intensif. Pencegahan yang dapat dilakukan oleh Departemen MKU ini termasuk dalam tiga aspek, sebagaimana pendapat Marzuki (Rakhmawati, 2012, hal. 93-94) radikalisme terdiri dari tiga tingkatan, yaitu: tingkat pertama adalah radical in mind (radikal dalam pemikiran), tingkat kedua radical in attitude (radikal dalam perilaku), dan tingkat ketiga adalah radical in action (radikal dalam tindakan). Pada tingkat radikal dalam pemikiran, perencanaan yang dilakukan oleh Departemen MKU harus berorientasi pada pengembangan kognitif mahasiswa baik dari unsur kenegaraan maupun unsur keagamaan, maka perlu ada sinergitas dalam proses perencanaan antara mata kuliah Pendidikan Kenegaraan dengan mata kuliah Agama dan Etika yang disesuaikan dengan kepercayaan mahasiswa. Pada tingkat radikal dalam perilaku, maka perencanaan pembelajaran harus berorientasi pada aspek afektif, hal ini menjadi penting karena rasa saling memiliki (sense of belonging) antar warga negara harus senantiasa diajarkan secara berkelanjutan. Jika perencanaan pada tahap ini berjalan dengan baik, maka selanjutnya perencanaan Departemen MKU perlu fokus pada aspek psikomotor karena dapat mencegah radikal dalam tindakan yang dilakukan oleh mahasiswa.

Dari unsur mahasiswa perencanaan yang dilakukan oleh organisasi kemahasiswaan menunjukkan adanya pembelajaran berorganisasi yang sangat baik, dimana perencanaan kegiatan yang dilakukan untuk satu tahun kedepan berdasarkan visi dan misi yang telah dibuat, hal ini menandakan adanya haluan yang jelas bagi organisasi dalam menjalankan kegiatannya. Selain itu, setiap program kegiatan organisasi kemahasiswaan disesuaikan dengan keadaan dan kebutuhan mahasiswa, sehingga kehadiran ormawa yang secara filosofis merupakan bentuk dari kehendak seluruh mahasiswa peran dan fungsinya dapat dirasakan. Hal ini menjadi penting karena kegiatan yang nantinya akan dilakukan, sangat dekat dengan mahasiswa, sehingga ormawa menjadi sangat strategis peran dan fungsinya dalam kegiatan deradikalisasi. Dalam penguatan kegiatan bela negara yang dilakukan oleh organisasi kemahasiswaan dengan cara melibatkan setiap unsur mahasiswa, hal ini menjadi penting karena pelaku organisasi kemahasiswaan bersentuhan 
langsung dengan kehidupan kampus. Maka peran dari organisasi kemahasiswaan ini menjadi sangat sentral untuk melakukan deteksi dini adanya pemikiran radikalisme yang masuk pada dunia kampus. Deteksi dini dari ancaman paham radikalisme dimulai dari adanya rasa memiliki mahasiswa terhadap perguruan tinggi, karena dengan cara ini mahasiswa dapat melakukan tindakan untuk mencegah paham radikalisme masuk ke dunia kampus. Hal tersebut didasarkan pada penelitian Ramadhan (2016, hal. 50-51) yang mengungkapkan bahwa dunia pendidikan memang sangat rentan untuk dijadikan lahan dimensi ideologi radikal. Karena sikap terlalu terbuka, akhirnya para pembawa ideologi radikal dapat masuk lewat kegiatan ekstrakulikuler keagamaan. Hal ini akan berdampak buruk pada terbentuknya watak yang monolitik, keras dan gemar menyalahkan orang lain.

Hasil penelitian Ramadhan tersebut menandakan bahwa perencanaan yang dilakukan oleh organisasi kemahasiswaan jangan hanya terfokus pada kegiatan-kegiatan formal, akan tetapi harus dapat hadir dalam setiap kehidupan yang ada di kampus, sehingga akan munculnya peran dari organisasi kemahasiswaan dalam penerapan kegiatan-kegiatannya. Secara menyeluruh kegiatan perencanaan kegiatan bela negara yang dilakukan oleh Institut Teknologi Bandung merupakan cara deteksi dini mengenai penyebaran paham radikalisme di dunia kampus, serta merupakan upaya mengembangkan model pendidikan yang berupaya untuk mencegah paham-paham radikalisme masuk pada dunia kampus. Hal tersebut sesuai dengan pendapat Arifin (Ramadhan, 2016, hal. 66) yang mengharuskan adanya deteksi dini dan pengembangan model pendidikan di perguruan untuk mencegah paham radikalisme.

\section{KESIMPULAN}

Berdasarkan uraian dalam artikel ini, maka dapat ditarik kesimpulan sebagai berikut; 1) peran strategis yang dilakukan Perguran Tinggi dalam menangani gerak radikalisme dilaksanakan melalui tiga jalur utama, yaitu jalur pendidikan melalui Mata Kuliah Umum (MKU), Rangkaian program pada Lembaga Kemahasiswaan Kampus serta organisasi kemahasiswaan; 2) Upaya bela negara yang dilaksankan oleh kampus bertitik tolak dari tiga jalur strategis kampus dengan pengoptimalan peran serta fungsinya masing - masing, yaitu Implementasi pembelajaran MKU yang Mengembangkan nilai - nilai kemanusiaan serta menjunjung tinggi toleransi diatas pluralitas yang ada, program lembaga kemahasiswaan dilaksanakan melalui pengembangan serangkaian program pro mahasiswa dengan basic penguatan intelektual, moral dan keterampilan. Selain itu, organisasi kemahasiswaan berkerja berdasarkan keadaan dan kebutuhan mahasiswa, sehingga kehadiran ormawa yang secara filosofis merupakan bentuk dari kehendak seluruh mahasiswa dapat terlealisasikan dengan baik.

\section{UCAPAN TERIMA KASIH}

Penelitian ini didukung oleh Kementerian Riset, Teknologi dan Pendidikan Tinggi melalui Program Penelitian Dasaran Unggulan Perguruan Tinggi Tahun Anggaran 2019. Peneliti pun mengucapkan terimakasih kepada LPPM UPI, para responden yang telah memberikan informasi berharga serta seluruh pihak yang telah mendukung dan membantu terlaksananya penelitian ini.

\section{DAFTAR PUSTAKA}

Apriliana, D. P., Raharjanti, A. I., Sulastri, A., Noviana, D., \& Nur, N. (2017). Respons mahasiswa terhadap kebijakan deradikalisasi pemerintah. Academica, 1(1), 96-109.

Arifuddin. (2016). Pandangan dan pengalaman dosen UIN Alauddin Makassar dalam upaya mengantisipasi gerakan islam radikal di kalangan mahasiswa. Al-Ulum, 16(2), 435. https://doi.org/10.30603/au.v16i2.160

Azca, M. N. (2013). Yang muda yang radikal: refleksi sosiologis terhadap fenomena radikalsime pemuda muslim pasca orde baru di Indonesia. Ma'Arif, 8(1), 14-44.

Azra, A. (1996). Pergolakan politik Islam: dari fundamentalisme hingga post-modermins. Jakarta: Paramadina.

Badan Nasional Penanggulangan Terorisme. (2016). Strategi menghadapi paham radikalisme terorisme - ISIS. Diambil dari http://belmawa.ristekdikti.go.id/wpcontent/uploads/2016/12/StrategiMenghadapi-Paham-RadikalismeTerorisme.pdf

BBC. (2011). Survei: hampir 50\% pelajar setuju tindakan radikal - BBC News Indonesia. Diambil 1 Maret 2020, dari https://www.bbc.com/indonesia/berita_ind onesia/2011/04/110426_surveiradikalisme

Capalbo, R. (2011). Global education brief. In Globalization. Diambil dari http://www.globalization101.com/uploads/ File/Education/Education.pdf

Hanani, A. F. (2013). Fenomena radikalisme pada kaum muda. Ma'Arif, 8(1), 4-13.

Pemerintah Republik Indonesia. (2010). Kebijakan nasional: pembangunan karakter bangsa 
Leni Anggraeni, dkk. Revitalisasi peran perguruan tinggi dalam menangani gerak radikalisme dan fenomena melemahnya bela negara di kalangan mahasiswa

tahun 2010-2025. In Pemerintah Republik Indonesia.

Rakhmawati, R. (2012). Pola pengasuhan santri di pondok pesantren dalam mengantisipasi radikalisme agama (studi perbandingan pondok pesantren ummul mukminin dan pesantren pondok madinah). Univeritas Islam Negeri Alauddin Makassar.

Ramadhan, H. (2016). Deradikalisasi paham keagamaan melalui pendidikan Islam rahmatan lil'alamin: Studi pemikiran Pendidikan Islam KH. Abdurrahman Wahid. Universitas Islam Negeri Maulana Malik Ibrahim.

Sholeh, M. (2007). Perencanaan pembelajaran mata pelajaran geografi tingkat SMA dalam konteks KTSP. Jurnal Geografi: Media Informasi Pengembangan dan Profesi Kegeografian, 4(2).

Susanti, R. (2013). Penerapan Pendidikan Karakter Di Kalangan Mahasiswa. AL-Ta lim, 1(6), 480-487.

https://doi.org/10.15548/jt.v20i3.46

Takwin, B., Mudzakkir, A., Salim, H., Ahnaf, M. I., \& Hamdi, A. Z. (2016). Studi tentang toleransi dan radikalisme di Indonesia: pembelajaran dari 4 daerah, Tasikmalaya, Jogyakarta, Bojonegoro Dan Kupang. Jakarta: Infid.

Ummah, S. C. (2012). Akar radikalisme di Indonesia. Humanika, 12(1), 112-124.

Wiktorowicz, Q. (2004). Introduction: Islamic activism and social movement theory $(\mathrm{Q}$. Wiktorowicz, Ed.). Bloomington \& Indianapolis: Indiana University Press. 